\title{
Vroue se belewenis van eensaamheid na die verlies van 'n lewensmaat: 'n Beskrywing van narratiewe pastorale betrokkenheid
}

Authors:
Annamarie de Beer ${ }^{1}$
Jan-Albert van den Berg'
Affiliations:
'Department of Practical
Theology, Free State
University, South Africa
Correspondence to:
Annamarie de Beer
Email:
adebeer@compuking.co.za
Postal address:
PO Box 339, Bloemfontein
9300, South Africa
Dates:
Received: 06 Mar. 2012
Accepted: 15 Aug. 2012
Published: 26 Nov. 2012
How to cite this article:
De Beer, A., Van den
Berg, J.A., 2012, 'Vroue se
belewenis van eensaamheid
na die verlies van 'n
lewensmaat: 'n Beskrywing
van narratiewe pastorale
betrokkenheid', Koers
- Bulletin vir Christelike
Wetenskap $77(2)$, Art. \#408,
org/10.4102/koers.v77i2.408

(C) 2012. The Authors. Licensee: AOSIS OpenJournals. This work is licensed under the Creative Commons Attribution License.
In hierdie bydrae word die fenomeen van eensaamheid wat deur vroue ervaar word na die verlies van 'n lewensmaat ondersoek. Die doel van hierdie studie is om die ervaring van eensaamheid sowel as die voorkoms en betekenis daarvan te verhelder en te interpreteer. Implikasies word ondersoek volgens die wyse waarop dit ervaar word. Die navorsing is gefundeer in praktiese teologie en nagevors vanuit postmoderniteit as paradigma met 'n sosiaal konstruksionistiese diskoers as epistemologiese vertrekpunt. Deur gebruik te maak van die kwalitatiewe navorsingsbenadering word verskeie aksies vir die insameling van data benut. Die navorsing word verder gerig deur die gebruik van meganismes van die narratiewe benadering, wat goed resoneer met die beginsels onderliggend aan deelnemende aksie-navorsing. Vanuit die gespreksbenadering word betekenisvolle alternatiewe, wat 'n bydrae kan lewer in die hantering van eensaamheid, verken en beskryf. Die vernaamste bevindings van die studie is dat vroue wel eensaamheid kan ondervind na die verlies van ' $n$ eggenoot en dat hulle ' $n$ behoefte het aan 'n verbintenisfiguur om hulle te help om hul eensaamheid te hanteer.

Women's experience of loneliness after the loss of a spouse: A description of a narrative pastoral engagement. In this contribution the phenomenon of loneliness experienced by women after the loss of a spouse is explored. The purpose of this research is to clarify and interpret the experience of loneliness as well as its occurrence and meaning. Implications are examined according to the way in which it is experienced. The research is founded in practical theology and researched from within a postmodernity paradigm, with a social constructionist discourse as epistemological point of departure. By employing the qualitative research approach, different courses of action are used for collecting data for the research. Principles underpinning participatory action research are employed as part of a qualitative research method. The research is further informed by using mechanisms of the narrative approach which correlate well with the principles of participatory action research. This conversational approach is used to explore and describe meaningful alternatives to cope with loneliness. The main findings of the research are that women do experience loneliness after the loss of a spouse and that they have a need for an attachment figure to help them to cope with the loneliness.

\section{Inleiding}

Sedert die laat 1960's het navorsing gedokumenteer dat eensaamheid wydverspreid is én 'n persoon se welstand kan ondermyn (Perlman 1989:19). In 'n poging om eensaamheid te beskryf, wys Potgieter (2010) daarop dat dit ervaar kan word as 'n gevoel van isolasie, betekenisloosheid en verwerping, wat dikwels lei tot die ervaring van minderwaardigheid. Volgens Blackwell (2010) is eensaamheid ' $n$ gevoel wat tot ' $n$ mens se diepste wese spreek en die behoefte van die individu om aan iemand te behoort en erken te word, verklank. Doman (2007:2) maak die afleiding dat eensaamheid die mens psigies sowel as fisies beïnvloed en dat dit verreikende gevolge vir die mens inhou. Dit stem ooreen met Potgieter (2010) wat reken dat eensaamheid 'n baie kragtige emosie is wat kan lei tot siekte, verslawing, depressie en selfmoord. Inleidend kan dus afgelei word dat eensaamheid enersyds algemeen voorkom en andersyds beslag kan lê op die individu se lewe. In 'n verdere ontwikkeling van voorafgaande navorsing (De Beer \& Van den Berg 2011:141-159) word daar in hierdie beskrywende navorsingsverslag in besonder gelet op die invloed van eensaamheid na die verlies van 'n lewensmaat by enkele vroue in die Kroonstad-omgewing. Alhoewel die titel van die navorsing in die algemeen na vroue verwys, is die klem in die artikel op 'n individuele en persoonlike belewenis wat nie veralgemeen kan word nie. Die beskrywende aard van die navorsing word verder bevestig deur 
die gebruik van die onbepaalde lidwoord om aan te dui dat slegs ' $n$ moontlike vergestalting van ' $n$ narratiewe pastorale betrokkenheid beskryf word.

\section{Landskap van die studie}

Die outeur is 'n pastorale terapeut in Kroonstad en het vroue wat vir terapie ingeskakel het as medenavorsers betrek. Met die begrip 'medenavorsers' word ' $n$ bepaalde betrokkenheid by individue wat deelneem aan die navorsing veronderstel (Müller, Van Deventer \& Human 2001:76), waarin gefokus word op die 'linking of people's lives with those of others in helpful ways, and in creating avenues by which insider-knowledges can be shared' (Morgan 2000:119).

$\mathrm{Na}$ aanleiding van talle gespreksgenote wat eensaamheid beleef, het die navorser besluit om die belewenis van eensaamheid by drie vroue tussen die ouderdomme van 55 en 65 jaar wat hulle lewensmaats verloor het, te ondersoek. Daar is op hierdie drie vroue besluit aangesien hulle die toonbeeld is van 'n ouderdomsgroep waarin die 'experience of widowhood becomes more likely with increasing age' (Louw 2008:503) en omdat hulle ervarings ' $n$ weerspieëling van die ander gespreksgenote se belewenisse is. In die gesprekke met die vroue het hulle illustratiewe inligting verskaf wat kon help om interpretasies met betrekking tot eensaamheid te verhelder.

Vrywillige deelname van mense 'waaroor' en 'waarvoor' navorsing gedoen word, is volgens Kotzé (2002:27) nodig om 'n etiese praktyk te vergestalt. Hierdie navorsing behels dus die verhale van vroue wat vrywillig hul belewenis en lewensomstandighede konstrueer en in taal omskryf. In die vertel van hul belewenisse beskryf die vroue in werklikheid 'n verhouding met daardie ervaring.

Die vroue se identiteit word beskerm deur die gebruik van skuilname en hulle verhale word met hulle toestemming in die navorsing gebruik. Slegs fragmente van gesprekke met medenavorsers word in direkte aanhaling gedokumenteer en op relevante plekke weergegee.

Hulle verhale word vervolgens inleidend en kortliks deur die navorser op sirkulêre wyse binne die beweging van die praktyk-teorie-model (Browning 1991:34-39) geskets ten einde die leser 'n blik op hulle lewens te gee:

'Marietjie is 63 jaar oud en het haar man vyf jaar gelede verloor. Hulle het geen kinders uit hulle huwelik nie. Sy is die enigste oorlewende van haar familie en het geen ondersteuningsisteem nie. Sy woon alleen in ' $n$ meenthuis en is volgens haar baie eensaam al is sy betrokke by die kerk se aktiwiteite. Volgens haar het sy die persoon wat haar lewe betekenisvol gemaak het, verloor. Hy was haar ondersteuning en het gehelp met alles. Nou moet sy self al die besluite neem en probleme oplos.

Ella is 60 jaar oud en haar man is vyf jaar gelede oorlede. Hulle het ' $n$ seun en dogter uit die huwelik, wat haar bystaan in tye van nood. Sy voel veral eensaam gedurende naweke en in die aande, wanneer sy nie besig is nie. Dit is vir haar baie moeilik om alleen na alles om te sien. Sy het nie meer iemand met wie sy probleme en besluite kan deel nie. Dit is nie meer vir haar lekker om kos te maak of naaldwerk te doen as daar nie iemand is vir wie sy dit doen nie.'
'Ansa is 65 jaar oud en haar man is vier jaar gelede oorlede. Hulle het vier dogters uit hulle huwelik, en hulle ondersteun haar. $\mathrm{Al}$ besoek haar dogters haar gereeld, voel sy baie eensaam. Sy woon alleen in ' $n$ huis met ' $n$ groot tuin. Dit alles hou haar baie besig en sy geniet dit om in die tuin te werk, maar beleef dit alles alleen. Sy soek iemand wat hierdie dinge met haar kan deel. Haar kinders is vir haar belangrik, maar sy kan nie alles met hulle bespreek nie en wil graag iemand in haar lewe hê wat haar bystaan.'

Daar word gepoog om die wyse waarop eensaamheid die sinvolle funksionering van die vroue raak op 'n pastoraalteologiese wyse te verken en te verhelder. Dié pastoraalteologiese verkenning veronderstel uiteraard 'n noue assosiasie met die omvangryke dinamika van die gemeenskap van gelowiges. Tereg merk McClure (2012:269) op dat 'the term pastoral care is particular to the Christian tradition, and grew out of the exigencies of congregational life. Pastoral care is thus elemental to religious life and organization.'

Met bogenoemde in ag genome is dit dus duidelik waarom juis die geloofsgemeenskap 'n ruimte moet skep vir 'koinonia, in order to support people who are to be healed and to help them discover meaning' (Louw 2008:27). In die volgende direkte aanhalings uit gesprekke met die vroue is dit duidelik op watter wyse eensaamheid nie net as as ' $n$ verhaal van nood ervaar word nie, maar dat dié gespreksgenote juis ook ' $n$ behoefte aan gesprek binne die koinonia-ruimte daaroor nodig het:

Marietjie: 'Dit help dat ek met iemand kan praat wat vir my riglyne kan gee hoe om hierdie eensaamheid te verlig.'

Ella: 'Ek sal van my kop af raak as ek nie kon praat oor hierdie eensaamheid nie.'

Ansa: 'Daar is nie regtig iets wat help nie, maar ek voel tog beter nadat ek oor hierdie eensaamheid met iemand kon praat.'

\section{Doel van die navorsingsprojek}

Die navorser poog om die ervaring, gevolge en betekenis van eensaamheid vir geïdentifiseerde vroue binne bepaalde sosiale strukture en kulture te beskryf. Slegs die belewenis van vroue word ondersoek, alhoewel mans ook eensaamheid na die verlies van 'n eggenoot kan ervaar. Dié keuse is ter bevestiging daarvan dat vir vroue 'die ervaring van 'n verlies heel ánders as dié van 'n man is' (Smit 2000:5). Toekomstige verdere navorsing oor verskillende persone met verskillende agtergronde kan die tema op 'n later tydstip verder verhelder.

Die navorsing fokus dus op die beskrywing van medenavorsers se belewenis van eensaamheid, met die oorkoepelende doel om by die vroue te leer watter gedagtes, gevoelens en beelde hulle met eensaamheid assosieer, watter soort verhoudings en mense hulle reken hulle eensaamheid kan verminder en waaruit hierdie voorstellings spruit.

\section{Navorsingsverwagtinge}

Die volgende navorsingsverwagtinge fokus op moontlike uitkomste van die studie:

- Vroue wat 'n lewensmaat verloor het, kan eensaamheid ondervind. 
- Die ervaring van eensaamheid na die verlies van 'n eggenoot het ' $n$ uitwerking op die daaglikse bestaan van vroue.

- Christenvroue se geloof speel 'n rol in hulle hantering en opvatting van eensaamheid.

- Die vroue se persepsie van eensaamheid kan deur middel van pastorale bystand verhelder word.

Aangesien ' $n$ bepaalde werkwyse benodig word om kennis vir hierdie navorsing in te win, word die metodologie vervolgens bespreek.

\section{Navorsingsprosedure en metodologie}

Metodologie word deur Schurink (1998:240) gesien as die 'researcher's perception of how he can find out about reality or the world.' Vir die praktiese teoloog beteken dit 'n verkenning van 'human experience and its desire to reflect theologically on that experience' (Swinton \& Mowat 2006:v). In hierdie studie word verskillende handelswyses vir insameling van inligting gebruik. Volgens Swinton en Mowat (2006:29) behels kwalitatiewe navorsing die aanwending van 'n verskeidenheid metodes en benaderings wat die navorser in staat stel om die sosiale wêreld te verken in 'n poging om toegang daartoe te verkry, asook om die unieke wyses waarop individue en gemeenskappe dit bewoon te kan verstaan. Die waarde van kwalitatiewe navorsing lê verder in die diversiteit van alternatiewe diskoerse wat vir navorsing gebruik kan word (Denzin \& Lincoln 1994:3).

Kwalitatiewe onderhoude word deur Botha (2001:15) as geskik beskou om inligting oor menslike ervaring en gedrag te ontgin. In hierdie navorsing word die narratiewe benadering beklemtoon deur gebruikmaking van ongestruktureerde sirkulêre vrae wat aan gespreksgenote gestel is en wat berus op ' $n$ belangstelling in mense se stories (Botha 2001:17). In dié aanpak kan egter hoogstens daarna 'gestreef' word om gedrag te verstaan. Die navorser poog slegs om insig te verkry in die wyse waarop mense gebeurtenisse ervaar en navorsingsresultate is nie geldig vir die hele bevolking nie.

Browning (1991:34-39) se benadering, waarin gebruik gemaak word van 'n sirkulêre beweging tussen praktyk en teorie, vorm die basis van die wyse waarop gesprekke met die vroue in hierdie studie omskryf word. Fragmente van hulle gesprekke word geposisioneer om die verband met die navorsing aan te dui.

\section{Aard en ruimte van die navorsing}

Data wat gedurende die navorsingsproses ingesamel word, sal volgens die navorser se verwysingsraamwerk geïnterpreteer word. Hiermee word erken dat 'the researcher brings his or her pre-understanding into the dialogue with the actions, meanings, and pre-understandings of the subjects' (Browning 1991:48). Ten einde 'n verantwoordbare oorsig te bied oor dié verwysingsraamwerk, word die volgende merkers aangestip:

\section{Paradigma}

Die operasionele raamwerk waarbinne feite geplaas word, kan gesien word, as die paradigma. Dit is ' $n$ stel oortuigings betreffende die aard of realiteit van die wêreld en hoe dit geken kan word, wat die navorser se persepsie vorm (Schurink 1998:240). Postmoderniteit word gesien as 'n gepaste raamwerk vir hierdie navorsing aangesien dit onder meer subjektiewe integriteit, beperktheid van taal en die misterie van verstaan veronderstel (Van den Berg 2006:168-171). Weens die erkenning van bogenoemde is postmoderniteit sensitief vir die eenvoudige en reglynige betekenis van byvoorbeeld Bybeltekste vir dié werklikheid. Dit erken die invloed van konteks(te) soos onder meer vergestalt in gebeure en omstandighede se invloed op, en betekenis vir die individu (De Beer \& Van den Berg 2008:48). Postmoderniteit erken veelvuldige interpretasies. Die vroue asook die navorser is deel van die sosiale konstruksie-diskoers.

Die uitgangspunt van die sosiale konstruksie-diskoers is, volgens Freedman en Combs (1996:6), onder meer die oortuigings, waardes, instellings, gewoontes, etikette, wette en verdeling van arbeid, wat die sosiale werklikheid vorm. Volgens Müller (1996:33) is dit 'n 'gedeelde konstruk binne ' $n$ interpreterende gemeenskap.' Die veronderstelling van die betrokke studie is dat hierdie gemeenskap primêr vanuit 'n koinoniale verwantskap funksioneer met die veronderstelling dat 'pastoral care is religious attention toward another' (McClure 2012:269). Aangesien die realiteit van 'n persoon nie objektief kenbaar is nie, word daar saam in dié gemeenskap van gelowiges gesoek na verborge én nuwe betekenisse. In dié proses word daar na die narratiewe van medenavorsers geluister. In deelnemende aksie-navorsing kry hierdie styl waarneembaar vorm. Alle narratiewe word ontgin met die doel om die vroue te bemagtig om sin en betekenis in hulle lewens te vind, al beleef hulle eensaamheid.

Die vraagstuk oor hoe daar tot kennis gekom word en wat die bron van kennis is, behels volgens Louw (1999:10) die epistemologie, wat vervolgens verhelder word.

\section{Epistemologie}

Schurink (1998:240) sê epistemologie behels 'the researcher's perceptions of where he stands in relation to reality or the world'. As navorser van hierdie studie posisioneer ek my in die kwalitatiewe navorsingsepistemologie. Aangesien kwalitatiewe navorsing, volgens Schurink (1998:240), gebruik maak van verskillende vakgebiede en tegnieke, is dit van toepassing op hierdie navorsing, waar kennis op verskillende maniere bekom word. Perspektiewe wat 'n rol speel in die verkryging van kennis sluit onder meer die volgende oriëntasies in:

- Sosiale konstruksie-diskoers: Soos reeds gestel, is die uitgangspunt van die sosiale konstruksie-diskoers, volgens Freedman en Combs (1996:6), onder meer die oortuigings, waardes, instellings, gewoontes, etikette, wette en verdeling van arbeid, wat ons sosiale werklikheid vorm. Dit word gekonstrueer deur lede van 'n kultuur soos hulle van dag 
tot dag, en generasie tot generasie, in interaksie verkeer. Binne postmoderniteit word aanvaar dat die mens nie in 'n wêreld met een enkele waarheid leef nie, maar in 'n omgewing met verskeie waarhede (De Beer 2007:15). Müller, Van Deventer en Human (2001:76-96) het reeds betekenisvol aangedui hoe die formulering van vrae as deel van narratiewe navorsing die vertel van verhale aanmoedig en versterk ten einde te bevestig dat 'as a hermeneutic mode of inquiry ... the process of inquiry flows from the question' (Josselson 1999:x). Dit is vanuit dié oriëntasie dat die sosiale aard van konstrukte waarbinne die vroue in 'n postmoderne konteks eensaamheid beleef, beskryf word.

- Die narratiewe benadering: Volgens Ganzevoort en Visser (2007:100) staan die narratiewe benadering in 'n hermeneutiese perspektief en poog dit om te verduidelik en te beskryf wat in die pastorale ontmoeting gebeur. Dit omskryf hoe die verhaal van mense en die verhaal van God mekaar raak en beïnvloed. Binne die benadering word die gespreksgenote gesien as medenavorsers en as deelnemers aan die gesprek en navorsing - 'the narrative researcher has subjective integrity in mind and strives for participatory observation' (Müller, Van Deventer \& Human 2001:3).

Ter uitdrukking van dié verstaansraam word die vroue se eie, unieke ervaring van eensaamheid en hulle konteks, waarbinne die onderlinge versorging van gelowiges 'n belangrike rol speel, beskryf. Dit vind aansluiting by 'n prakties-teologiese hermeneutiek wat oor die interpretasie van menslike handelinge binne sosiale kontekste handel (Louw 1997:56). Vervolgens word die prakties-teologiese plasing beskryf.

\section{Prakties-teologiese plasing}

Browning (1991:9) beskryf praktiese teologie as 'n multidissiplinêre wyse om teologie aan te pak. Dit omvat praxis sowel as teorie en die twee staan in 'n voortdurende sirkulêre beweging teenoor mekaar (Browning 1991:6). Die studie vind aansluiting by die gedragsdimensie binne die praktiese teologie. Dit behels die gereedmaak en handelswyse van die navorsing. Kruger (2000:30) reken dat die teorie by die meeste praktiese teoloë 'n normatiewe karakter dra, terwyl die praxis 'n beskrywende karakter dra. Volgens Osmer (2008:328) is daar 'n nuwe begrip en ontwikkeling binne die praktiese teologie. Dit omvat 'n aksie-begeleide konstruksie-teorie van die Christen-praxis in 'n spesifieke sosiale konteks waarin die erkenning van die normatiewe karakter van onderlinge koinoniale versorging, soos onder meer uitgedruk in die pastoraat, erken word. Hy identifiseer die volgende vier take wat verband hou daarmee (Osmer 2008:4-12):

- Die deskriptiewe-empiriese taak wat handel met die vraag oor wat aangaan of wat gebeur.

- Die interpreterende taak wat die vraag vra oor hoekom dit gebeur.

- Die normatiewe taak wat die vraag stel oor wat behoort te gebeur.
- Die pragmatiese taak wat handel oor die vraag oor hoe gereageer kan word.

Volgens Fourie (2010:32) kan die onderlinge verhouding van Osmer se vier take as ' $n$ hermeneutiese sirkel, waar elke taak deel van 'n groter interverwante geheel is, gesien word. Die pastoraat veronderstel ontmoetingsgebeure waartydens hierdie take na vore tree.

Müller (2009:205) sien praktiese teologie as 'always concrete, local, and contextual', maar ook as iets wat 'reaches beyond local contexts to transdisciplinary concerns.' Sy benadering dwing ons om eerstens na die verhale van mense in werklike lewenssituasies te luister (Müller 2009:205). Ervaring is geleë binne ' $n$ konteks en word altyd geïnterpreteer. Daar is dus 'n klemverskuiwing vanaf die subjektiewe tot diskoers.

Hierdie navorsing word vanuit 'n kwalitatiewe, hermeneutiese benadering van praktiese teologie gedoen. Dié perspektief behels volgens Gerkin (1986:61) 'n proses van verklarende samesmelting van horisonne van betekenis. Die betrokkenheid en deelname van gespreksgenote hou verband met beginsels onderliggend aan deelnemende aksienavorsing en daarom word die praxis beklemtoon. Die doel van ' $n$ hermeneutiese verstaan handel onder meer met die ontdekking van betekenisvolle verbande binne 'n geloofsgemeenskap(pe) tot realisering van singewing as uitkoms (Müller 1996:8-12; Louw 1999:22-23). Beide praktiese teologie en die pastoraat fokus op die sinvolle funksionering en geestelike groei van mense.

\section{Pastoraat}

Die pastoraat kan wesenlik gesien word as 'n teologiese vakgebied wat poog om mense te help om sinvol te leef en om 'n samehang met hulle verstaan van God en basiese lewensvraagstukke, soos angs, skuld, wanhoop en vertwyfeling, te bewerkstellig. Heitink (1979:289-311) sien heling, bystand, begeleiding en versoening as funksies van die pastoraat. Al vier funksies van die pastoraat kom nie gelyktydig aan die orde nie. Een bepaalde funksie tree gedurende 'n spesifieke tyd, onder bepaalde omstandighede en afhanklik van die konteks op die voorgrond (Heitink 1998:127). Een van die pastor se primêre take binne die geloofsgemeenskap is om na die stories van mense te luister en om dit te interpreteer (Müller 1996:107).

Hierdie karaktertrekke van die pastoraat beteken dat dit primêr handel met die interaksie en kommunikasie van die ontmoeting tussen God en die mens. Die volgende direkte aanhalings wys daarop dat geloof ' $n$ rol speel by die vroue se hantering van eensaamheid.

Marietjie: 'As ek nie 'n Christen was nie, het ek na my man se dood lankal tou opgegooi. Hierdie ervaring het my geleer om nader aan God te beweeg.'

Ella: 'Die Here gee my krag om aan te gaan in moeilike en alleentye. Hy vertroos my.'

Ansa: 'Dit help om met medegelowiges te kommunikeer al verstaan hulle nie hoe dit voel om eensaam te wees nie. My geloof maak dit tog makliker om nadat my man oorlede is die eensaamheid van alleenwees te kan hanteer.' 
Die pastoraat poog om God se wil met betrekking tot die vraag na die sin van die lewe, en omgekeerd, te vertolk, sodat medegelowiges met vreugde en hoop kan leef (Louw 1999:2). In hierdie geval behels dit die taak om die ervaring van eensaamheid na vreugde en hoop om te skakel. Die lewe moet weer sinvol raak vir die vroue. Die pastoraat wil hierdie lewensvraagstukke sinvol vanuit die Christelike geloofsperspektief aanspreek. Dit wil aan die vroue hulp verleen en hoop bied. Eensaamheid is 'n gevoel wat tot 'n persoon se diepste wese spreek en omvat die behoefte om aan iemand te behoort en erken te word. As gevolg van eensaamheid is daar 'n onontkombare begeerte om 'n verhouding met die self, ander en God te hê.

Dit lei tot die vraag oor die wyse waarop die ervaring van die vroue se verlies verband hou met die eensaamheid wat hulle ervaar. Die volgende direkte aanhaling-fragmente van hulle gesprekke gee meer duidelikheid hieroor.

Marietjie: 'Na my man se dood het ek nie meer 'n sielsgenoot gehad om my te ondersteun nie. Die besef het my verskriklik alleen laat voel.'

Ella: 'Ek het na my man se dood baie eensaam gevoel. Dit was asof niks daardie leemte kon vul nie.'

Ansa: 'Die dood was vir my moeilik om te verstaan. Die ergste was dat ons nooit weer met mekaar kon praat nie. Ek het alleen en eensaam gevoel.'

Om die dinamika van die eensaamheid wat deur die vroue ervaar word beter te verstaan, word dit vervolgens aan die orde gestel.

\section{Die oppervlakte-struktuur van eensaamheid}

Eensaamheid word volgens Spitzberg en Hurt (1989:157) beskryf as ' $n$ 'deficit of desired relational interaction'. Hulle skryf verder dat dit ' $n$ staat van ontevredenheid met betrekking tot die kwaliteit en kwantiteit van interpersoonlike verhoudings is. Daar word dus 'n probleem ervaar. Volgens Stokes (1989:59) kan eensaamheid beskryf word, maar nie werklik gedefinieer word nie.

\section{Eensaamheid as 'n probleem}

Doman (2007:4) skryf dat eensaamheid gesien word as 'n subjektiewe ervaring wat deur verskeie veranderlikes beïnvloed word. Daar is by eensaamheid twee aspekte teenwoordig van belang is. Eerstens word eensaamheid ervaar as gevolg van swak sosiale verhoudings, waar die basiese behoeftes van die persoon nie bevredig word nie en tweedens as ' $n$ onaangename en soms pynlike verlange na meer interaksie as wat tans ervaar word (Wintrob 1989:80).

Marietjie: 'Daar is niemand wat regtig vir my omgee nie. Ek moet altyd alles alleen doen.

Ella: 'Ander mense gee tog nie om wat met jou aangaan nie. Almal leef net vir hulle self.'

Ansa: 'Ek pas nêrens in nie. Getroude vroue sien my as 'n bedreiging al is my bedoeling hoe goed.'
Daar is baie faktore wat ' $n$ rol speel by die ervaring van eensaamheid na verlies, onder meer wat die aard van die verhouding met die gestorwe geliefde was, ondersteuningstrukture en die konteks waarin die vrou haar bevind. Elke vrou ervaar verlies op 'n unieke, persoonlike manier (Smit 2000:5). Dit kan selfs gebeur dat die vroue hul lewensin verloor as gevolg van hul eensaamheid.

Marietjie: 'My hele wese is leeg en onvergenoegd.'

Ella: 'Ek staan soggens op, eet outomaties, praat maar is nie deel van wat gesê is nie, gaan saans slaap en hoor maar wil nie luister nie. Dit is nie die lewe nie.'

Ansa: 'Dit voel asof ek die enigste mens op aarde is en in 'n maalstroom van pyn en verlange kan uitskreeu.'

Spitzberg \& Hurt (1989:157) wys daarop dat eensaamheid ook geassosieer kan word met verskeie persoonlikheidsteurings, wat onder meer lae selfbeeld, depressie, selfmoord-fantasieë en angs insluit.

Marietjie: 'Alleen skep 'n probleem. Ek het geen selfvertroue meer nie en pas nêrens in nie.'

Ella: 'Ek het teruggesak in 'n bestaanswyse waar weinig dinge van belang is.'

Ansa: 'Ek voel hulpeloos, wanhopig, onbeholpe en verskriklik afhanklik. Soms wonder ek of ek nie 'n einde aan hierdie lewe moet maak nie.'

Daar is ook moontlikhede van 'n alternatiewe reaksie waar uitsigte en lewensruimte kan vergroot. 'n Vrou wat lank gelukkig getroud was, sal die dood van haar man anders beleef as iemand wat ongelukkig getroud was (Smit 2000:6). In sommige gevalle, soos langdurige terminale siektetoestande of swak verhoudings, kan daar selfs 'n gevoel van verligting ervaar word. Louw (2008:555) meen egter 'relief should, however, be perceived as a normal reaction and could be most positive, especially if the griever can combine it with gratitude.' Hierdie studie fokus egter op eensaamheid wat ervaar word na die verlies van 'n eggenoot.

\section{Die aard van eensaamheid}

Volgens Doman (2007:6) is eensaamheid 'n unieke en subjektiewe ervaring vir elke persoon. Dit is belangrik om daarop te let dat eensaamheid 'n persoonlike ervaring is en konsepte daarvan sal dus verskil van persoon tot persoon. Betekenisse en ervaringe verskil van persoon tot persoon. Weiss (1989:8) reken dat die probleem met baie omskrywings van eensaamheid die siening is dat dit omskryf kan word deur die toestande wat teoreties daartoe aanleiding gegee het. Weiss (1989:10) verstaan eensaamheid as 'separation distress without an object'. As dit gebeur, kry die individu die behoefte aan 'n 'attachment figure' se gerusstellende teenwoordigheid. Die individu sonder so 'n verbintenisfiguur voel eensaam, soos dit ook blyk uit die vroue se woorde.

Marietjie: 'Ek het geen ondersteuning nie, iemand wat hierdie eensaamheid kan help verminder nie.'

Ella: 'Daar is niemand saam met wie ek kan lag en gesels nie.'

Ansa: 'Ek wil tog net een keer weer voel hoe dit is om iemand naby my te hê.' 
Die verbintenisfiguur kan dan gesien word as ' $n$ persoon wat sekuriteit voorsien as gevolg van 'n perseptuele en emosionele skakeling met die eensame. Die konsep word vervolgens verhelder.

\section{Verbintenisfiguur ('Attachment figure')}

Die behoefte aan 'n verbintenisfiguur ('attachment figure') blyk ' $n$ rol te speel in die belewenis van eensaamheid. By kinders word die moeder as die 'attachment figure' gesien (Bowlby 1973:22). Hy skryf ook dat die begrippe 'attachment figure' en 'support figure' enige persoon is tot wie 'attachment'-gedrag gerig is (Bowlby 1973:23). Volgens Weiss (1989:11) is die verbintenisfiguur ('attachment figure') nie dieselfde as iemand wat naby, intiem betrokke of ' $n$ vertroueling is nie. Die veronderstelling is dat dit iemand is wat genoeg omgee om met duidelike begrip te luister en wat toeganklik (ontvanklik) is vir vertroulike mededelings. Die teenwoordigheid van hierdie soort figuur weer die angs, wat uiteindelik na depressie lei, af. Die vind van ' $n$ moontlike verbintenisfiguur kan dus ' $n$ rol speel wanneer eensaamheid ondervind word na die verlies van 'n eggenoot.

\section{Transformasie van verbintenis}

In gevalle waar vroue hulle lewensmaats verloor het, is daar 'n objek wat in die geval van eensaamheid geassosieer word met die gebrek aan 'n verbintenisfiguur. Aandag en denke word op die verlore objek gefokus. Hierdie objek kan nie maklik ontdek of verplaas word deur 'n ander nie (Wood 1989:44-45).

\section{Verhoudings en eensaamheid}

Eensaamheid maak 'n persoon bewus van die gebrek aan 'n verbintenisfiguur en wys dikwels hoe 'n persoon van die volgende drie tipe verhoudings gedistansieer kan raak:

- Verhouding met myself: Eensaamheid bring dikwels die behoefte om jouself te ken aan die lig. Dit openbaar 'n behoefte aan afsondering of emosionele isolasie waar die mens ' $n$ bietjie moet stilsit en ' $n$ kans kry om te hoor, te luister, te wag, te rus en te vertrou wat in die hart omgaan (Blackwell 2010). Die saad van wense, behoeftes, begeertes en hoop moet binne 'n persoon se hart geplant en versorg word.

Een van die redes vir eensaamheid in die moderne tyd is die klem wat op onafhanklikheid geplaas word. Mense sorg vir hulleself en het nie eintlik iemand anders nodig nie. Alles waarop 'n persoon hoop en wat hy of sy nodig het, kan self voorsien word. Die uiteinde daarvan is nog meer isolasie en eensaamheid.

- Verhouding met ander: Die eensaamheid van sosiale isolasie kan omskryf word as 'the distress which is part of the loneliness of social isolation [and which] has more to do with vulnerability than with loss of something desired' (Weiss 1989:13). Dit gaan nie oor die pret wat misgeloop word nie, maar eerder daaroor dat 'n mens op sy of haar eie, sonder 'n bondgenoot in 'n gevaarlike wêreld, moet leef. Eensaamheid laat 'n persoon na erkenning en intimiteit soek ten einde 'n ruimte van aanvaarding, erkenning en liefde te skep. Dit is ook volgens Pike (1953:95) 'a reflection of the fact that we are not whole ourselves: our lives must be interlaced with others if we are to be fulfilled.' As iemand aanvaar word vir wie daardie persoon werklik is, kan die betrokkene nie anders as om vervulling te smaak nie. Die mens kan dan vanuit dié verhouding 'n passie vir die lewe op 'n verskeidenheid van vlakke met ander deel (Blackwell 2010).

- Verhouding met God: Die mens se hart sal altyd 'n soort eensaamheid ondervind wat vir solank as wat 'n persoon lewe nooit heeltemal beantwoord sal word nie. Hierdie alleenheid wakker'n emosionele en geestelike verlange na God aan. In jou hart wil jy wees waar die wonder, viering, passie en vervulling nooit eindig nie. Die mens wil by die bron daarvan uitkom (Blackwell 2010).

\section{Potensiële faktore by eensaamheid}

Eensaamheid word gesien as 'n faktor wat 'n rol speel in 'n wye verskeidenheid probleme wat ' $n$ potensiële gevaar vir die mens se gesondheid inhou (Lauder, Sharkey \& Mummery 2004:88-94). Eensaamheid is daarom dikwels 'n teelaarde vir verkeerde besluite (Blackwell 2010).

Marietjie: 'Ek het nie meer lus om kos te maak nie en eet sommer enige iets wat beskikbaar is.'

Ella: 'Hierdie alleenheid maak dat ek net wil koop, al het ek niks nodig nie.'

Ansa: 'Ek klim sommer sesuur in die aand in die bed met sjokolade en lê en TV kyk.'

Dit is uit bostaande fragmente duidelik dat eensaamheid 'n invloed het op die besluitneming van die gespreksgenote.

Nog faktore wat met eensaamheid geassosieer kan word, is:

- Weerloosheid asook 'the lack of confidence in one's ability to provide for and protect oneself' (Stokes 1989:57).

- Dikwels is eensame persone 'mildly depressed; such individuals are prone to be apathetic and imply that nothing seems to work to relieve their difficulties' (Perlman \& Joshi 1989:67)

- Eensame persone openbaar dikwels 'negative judgment of self and others' (Shaver \& Hazan 1989:117).

- Van Niekerk (2002:101-108) noem dat skuldgevoelens, ambivalente herinneringe, geskonde herinneringe, voltooide herinneringe, onderbreekte kommunikasie en onvoltooide verwerking van verliese ervaar kan word.

- Volgens (Kübler-Ross \& Kessler 2005:81-82) het die eensame persoon ' $n$ 'abnormal, lonely, and unwelcome world' betree waar daardie persoon niks meer as 'n eiland van swaarmoedigheid is nie.

\section{Die oorsaak van eensaamheid}

Volgens die gespreksgroep in die navorsing is alleenheid, onsekerheid en 'n gebrek aan ondersteuning vir hulle die moeilikste om te hanteer. Pike (1953:106) skryf dat 'loneliness comes from the lack of a deep and abiding basis of connection 
between people.' Volgens Weiss (1989:10) is die gebrek aan 'n verbintenisfiguur' $n$ rede waarom iemand eensaam voel.

Marietjie: 'Ek het niemand om vertroulike of lekker dinge mee te deel nie.'

Ella: 'Ek weet nie meer hoe om op te tree nie. Ek voel onseker en het nie meer 'n goeie selfbeeld nie.'

Ansa: 'As daar tog net iemand was wat my kan help om besluite te neem. Die verantwoordelik het vir my te veel geword.'

Daar is talle perspektiewe met betrekking tot faktore wat eensaamheid laat ontstaan. Hoe langer' $n$ persoon eensaamheid ervaar, 'the more his or her causal explanations for the loneliness shift from external, controllable, unstable and situational causes to internal, uncontrollable, stable, and chronic cause' (Spitzberg \& Hurt 1989:157). Chroniese eensame persone begin glo dat hulleself die oorsaak van hulle eensaamheid is, waar situasionele eensaamheid ' $n$ persoon sal motiveer om die eensaamheid te hanteer deur interpersoonlike kontak te soek.

Dit is duidelik dat al drie hierdie vroue eensaamheid ervaar wat gekoppel kan word aan omstandighede met betrekking tot die verlies van hulle lewensmaats. 'n Pastoraalterapeutiese benadering sal dus fokus op hulle opvatting hiervan en die moontlike soeke na alternatiewe betekenisaksente.

\section{Pastorale terapie vir die eensame}

Die navorser soek met behulp van die hermeneutiese proses na die betekenis van die ervaring van eensaamheid wat spruit uit die verlies van 'n eggenoot. Volgens Louw (1999:23) wil 'n hermeneutiese benadering nie in die besonder verklaar nie. Dit wil eerder verbande ontdek met die oog op singewing. Endres (2009:117) skryf dat 'die pastoraat minder by die verklaring van probleme betrokke is en meer by die verstaan van menslike probleme.' Die narratiewe vertellings van die gespreksgenote sal 'n bydrae lewer tot die konstruering van 'n diverse verhaal. 'n Hermeneutiese kyk op die realiteit is volgens Müller (1996:19) 'ook 'n narratiewe kyk op die werklikheid'. Deur herinterpretasie en herstrukturering van die vroue se verhale, word beoog om verandering te fasiliteer, sodat die vroue betekenis kan vind. Dit kan moontlik daartoe bydra dat hulle weer vervulling in hulle lewens sal vind. Die volgende fragmente van gesprekke oor die waarde van terapie dui op die vroue se ervaring daarvan.

Marietjie: 'Gelukkig het die Vader dit so beskik dat ek by iemand uitkom wat vir my die las van eensaamheid ligter gemaak het. Dit is asof ek nou weer rigting het. Daar is weer hoop om gelukkig te kan wees in my lewe.'

Ella: 'Met die terapeutiese hulp kon ek bepaal wat die logiese van my bestaan behoort te wees. Daar is ook nou vir my moontlikhede wat hierdie emosies meer draagbaar maak.'

Ansa: 'Ek het besef dat ek nie om hierdie probleem kan stap nie, maar dat ek regdeur moet gaan. Met hierdie gesprekke kon ek weer die doel van die lewe sien en dat God weer waarde gee aan my bestaan.'
Dié voorstelling van 'n pastoraal-terapeutiese benadering is om vroue binne die reliëf en kontoere van die Christelike geloofsgemeenskap te bemagtig ten einde die ontwikkeling van hoop in die hantering van eensaamheid na die verlies van 'n eggenoot te fasiliteer. Indien daar nie 'n moontlikheid van ' $\mathrm{n}$ verbintenisfiguur is nie, moet gepoog word om eensaamheid in die bepaalde omstandighede te hanteer. Die narratiewe benadering laat nie ruimte vir direktiewe voorstelle nie, aangesien die hantering van eensaamheid by medenavorsers gefasiliteer moet word. Dit kan egter moontlik met behulp van alternatiewe voorstelle gefasiliteer word. Moontlike alternatiewe om die hantering van eensaamheid te fasiliteer word vervolgens bespreek. Dit is 'n samestelling van die navorser se insette na aanleiding van gesprekke met medenavorsers en van Potgieter (2010) en Blackwell (2010) se sienings:

- Reik uit na mense. Bly betrokke by aktiwiteite in die gemeenskap.

- Luister aandagtig na wat iemand sê, vergeet van jouself en toon opregte belangstelling en empatie. Bly intellektueel aktief.

- Bou goeie verhoudings deur 'n vriend te wees vir iemand anders.

- Skakel in by nuwe situasies. Sluit aan by 'n klub of doen vrywillige werk vir 'n organisasie. Kry 'n nuwe interessante stokperdjie.

- Wanneer daar niemand is wat saam met jou kan of wil gaan nie, gaan dan alleen. Dit is juis wanneer jy op jou eie inskakel by ' $n$ nuwe situasie of groep dat jy uit die web van eensaamheid loskom.

- Hou op om passief te wees en raak aktief. Reis indien dit binne jou vermoë is. Verbreed jou horisonne.

- Moenie emosionele seerkry of traumatiese gebeure van jou kinderjare of verlede onderdruk nie. Hanteer hierdie herinneringe ten einde dit sinvol in jou lewensverhaal te integreer en om ander in dieselfde situasie te bemoedig.

- Moenie skaam of bang wees om aan te klop vir hulp nie. Wanneer jy depressief en eensaam voel, moet jy met iemand praat wat sal luister.

Uit bogenoemde kan gespreksgenote ' $n$ plan saamstel om eensaamheid te kan hanteer. Dit bly egter gespreksgenote se eie keuses en besluite.

Eensaamheid kan ook positiewe waarde hê. Deur die pyn van eensaamheid kan die vroue leer om hulleself beter te ken en die diepte van hulle eie-ek en menswees ontdek. Volgens Weiss (1989:11) kan die hantering van eensaamheid daartoe lei dat ' $n$ persoon se selfvertroue vermeerder. Eensaamheid kan die kreatiewe inspirasie wees vir selfontdekking en persoonlike groei. Eensaamheid kan oorkom word, en indien dit hanteer word, ontsluit dit nuwe moontlikhede en potensiaal.

\section{Navorsingsbeperkings}

Veranderlikes wat moontlik 'n beperkende rol kon speel, is onder meer die keuse van 'n homogene groep Afrikaanssprekende vroue uit dieselfde kultuurkonteks met onder meer ooreenstemmende wyses van uitdrukking in spirituele 
oriëntasie. Die getal medenavorsers kan ook as 'n moontlike beperking gesien word. Dit moet egter in gedagte gehou word dat op grond van die navorsingsraam daar in die eerste plek nie gefokus word op algemene afleidings nie, maar dat die klem op die individuele en persoonlike is.

\section{Slot}

Deur huweliksmaats met bome te vergelyk, maak Van Niekerk (2002:76) die afleiding dat een boom moeilik staande bly indien die ander wegval, want 'dit kwyn weg'. Perspektiewe vanuit die gedokumenteerde navorsing veronderstel dat dit ingebed is in pastorale betrokkenheid teen die agtergrond van die Christelike geloofsgemeenskap. Aangesien hierdie navorsing 'n pastorale studie is, het die navorser voortdurend gepoog om die vroue se verhale te verstaan en te interpreteer met God se verhaal in gedagte. Ter oriëntasie van dié pastorale houding is die veronderstelling: 'in die narratiewe proses besef die mens dat normatiewe beantwoording ten opsigte van menslike gedragswyses gemaak moet word ten einde dit in ooreenstemming met Bybelse norme te bring' (Moore 2004:308). Hierdie oriëntasie bied daarom 'n eie pastoraal-teologiese aksent aan die aard, karakter, inhoud en uitkomste van die gedokumenteerde navorsing, onder meer in perspektiewe vanuit die literatuurstudie en fragmente van mede-navorsers se gesprekke.

Ter samevatting is dit dus duidelik dat, volgens die aangeduide vroue se narratiewe, hulle eensaamheid ervaar na die verlies van 'n eggenoot. Die ervaring van eensaamheid het ' $n$ duidelike uitwerking op die vroue se leefwyse gehad. Dit het ook voorts geblyk dat hulle 'n behoefte ontwikkel het aan 'n sogenaamde verbintenisfiguur of 'attachment figure' wat ' $n$ rol kon speel wanneer eensaamheid ondervind is. Die veronderstelling is dat hierdie figuur moontlik hoop en vervulling in hulle daaglikse bestaan kon bied. Dit was egter ook duidelik dat Christenvroue se geloof 'n belangrike rol gespeel het in hulle hantering van eensaamheid. Daar is aangetoon dat die vroue se opvatting van eensaamheid deur middel van pastorale betrokkenheid, as uitdrukking van die onderlinge versorging van gelowiges, verhelder kon word tot die vind van nuwe betekenismoontlikhede.

\section{Erkenning \\ Mededingende belange}

Die outeurs verklaar dat hulle geen finansiële of persoonlike verbintenis het met enige party wat hulle nadelig of voordelig kon beïnvloed in die skryf van hierdie artikel nie.

\section{Outeurbydraes}

Die outeurs A. de B. (Universiteit van die Vrystaat) en J-A. v.d.B (Universiteit van die Vrystaat) het gelyke bydraes gelewer tot die navorsing en skryf van hierdie artikel.

\section{Literatuurverwysings}

Blackwell, M.S., 2010, Moenie bang wees vir eensaamheid nie, besigtig op 19 Desember 2010, by http://www.mrf.za.net/modules/ftpdocs/users/
Botha, P., 2001, 'Die kwalitatiewe onderhoud as data-insamelingstegniek: Sterk en swak punte', Journal of Family Ecology and Consumer Sciences 29, 13-19.

Bowlby, J., 1973, 'Attachment and loss: Volume II: Separation, anxiety and anger', in M. Masud \& R. Khan (eds.), The international psycho-analytical library 95, 1-429, The Hogarth Press \& The Institute of Psycho-Analysis, London.

Browning, D.S., 1991, A fundamental practical theology: Descriptive and strategic proposals, Fortress, Minneapolis.

De Beer, A., 2007, 'Afsluiting na die verlies van 'n kind -' $n$ Narratiewe pastorale studie van 'n moeder(s) se belewenis', Magister-skripsie, Universiteit van die Vrystaat, Bloemfontein.

De Beer, A. \& Van den Berg, J-A., 2008, “'Afsluiting” na die verlies van 'n kind: ' Narratiewe pastorale studie van 'n moeder(s) se belewenis(se)', Praktiese Teologie in Suid-Afrika 23(2), 44-61.

De Beer, A. \& Van den Berg, J.A., 2011, “n Diskoers oor eskatologie en promissioterapie by vroue na die verlies van 'n eggenoot', In die Skriflig 45(1), 141-159.

Denzin, N.K. \& Lincoln, Y.S., 1994, 'Introduction: Entering the field of qualitative research', in N.K. Denzin \& Y.S. Lincoln (eds.), 2000, Handbook of qualitative research, 2de uitgawe, pp. 1-17, Sage, VSA.

Doman, L.C.H., 2007, 'Die verband tussen eensaamheid en psigologiese welstand by derdejaarstudente: 'n Kruiskulturele ondersoek', MSocSc-skripsie, Departement Sielkunde, Fakulteit Geesteswetenskappe, Úniversiteit van die Vrystaat, Bloemfontein.

Endres, A., 2009, 'Getraumatiseerde adolessente se soeke na hoop: 'n Pastorale model', PhD-proefskrif, Universiteit van Pretoria, Pretoria.

Fourie, M.C.F., 2010, 'Middelloopbaan-ontwikkeling deur spirituele lewenstylafrigting', PhD-proefskrif, Departement Praktiese Teologie, Fakulteit Teologie, Universiteit van die Vrystaat, Bloemfontein.

Freedman, J. \& Combs, G., 1996, Narrative therapy: The social construction of preferred realities, Norton, New York.

Ganzevoort, R.R. \& Visser, J., 2007, Zorg voor het verhaal. Achtergrond, methode en inhoud van pastorale begeleiding, Meinema, Zoetermeer.

Gerkin, C.V., 1986, Widening the horizons: Pastoral responses to a fragmented society, Westminster Press, Philadelphia.

Heitink, G., 1979, Pastoraat als hulpverlening: Inleiding in de pastorale theologie en psychologie, Kok, Kampen.

Heitink, G., 1998, Pastorale zorg: Theologie, differentiatie, praktijk. Handboek Praktische Theologie, Kok, Kampen.

Josselson, R., 1999, 'Introduction', in R. Josselson \& A. Lieblich (eds.), Making meaning of narratives: The narrative study of lives. Volume 6, pp. ix-xiii, Sage, London.

Kotzé, D., 2002, 'Doing participatory ethics', in D. Kotzé, J. Myburgh, J. Roux et al. (reds.), Ethical ways of being, pp. 1-34, Ethics Alive, Pretoria.

Kruger, S.F., 2000, 'Menslike persoonlikheid en toerustende herderlike bediening: Aspekte van 'n metateorie, basisteorie en praktykteorie', PhD-proefskrif, Potchefstroomse Universiteit vir Christelike Hoër Onderwys, Potchefstroom.

Kübler-Ross, E. \& Kessler, D., 2005, On grief and grieving: Finding the meaning of grief through the five stages of loss, Simon \& Schuster, London.

Lauder, W., Sharkey, S. \& Mummery, K., 2004, 'Nursing and health care management and policy: A community survey of loneliness', Journal of Advanced Nursing 46(1), 88-94.

Louw, D.J., 1997, 'Hoe teologies is die praktiese teologie en hoe prakties is die teologie? Ontwerp vir 'n prakties-teologiese hermeneutiek', Praktiese Teologie in Suid-Afrika 12(2), 43-63.

Louw, D.J., 1999, Pastoraat as vertolking en ontmoeting: ' $n$ Teologiese ontwerp vir 'n basisteorie, antropologie, metode en terapie, hersiene uitgawe, Lux Verbi, Kaapstad.

Louw, D., 2008, Cura Vitae. Illness and the healing of life, Lux Verbi.BM, Wellington.

McClure, B., 2012, 'Pastoral Care', in B.J. Miller-McLemore (ed.), The Wiley-Blackwell Companion to Practical Theology, pp. 269-278, Wiley-Blackwell, Oxford.

Moore, A.G., 2004, " $n$ Narratief-pastorale benadering in maatskaplike werk', PhDproefskrif, Universiteit van die Vrystaat, Bloemfontein.

Morgan, A., 2000, What is narrative therapy? An easy-to-read introduction, Dulwich Centre Publications, Adelaide.

Müller, J., 1996, Om tot verhaal te kom, RGN, Pretoria.

Müller, J., Van Deventer, W. \& Human, L., 2001, 'Fiction writing as metaphor for research: A narrative approach', Practical Theology in South Africa 16(2), 76-96.

Müller, J., 2009, 'Transversal rationality as a practical way of doing interdisciplinary work, with HIV and Aids as a case study', Practical Theology in South Africa 24(2), 199-228.

Osmer, R.R., 2008, Practical theology: An introduction, Wm B Eerdmans, Michigan.

Perlman, D., 1989, 'Further Reflections on the present state of loneliness research', in M. Hojat \& R. Crandall (eds.), Loneliness: Theory, research and applications, Sage, London.

Perlman, D. \& Joshi, P., 1989, 'The relationship of interpersonal competence and skills to reported loneliness across time', in M. Hojat \& R. Crandall (eds.), Loneliness: Theory, research and applications, Sage, London.

Pike, J.A., 1953, Beyond Anxiety. The Christian answer to fear, frustration, guilt, indecision, inhibition, loneliness, despair, Charles Scribner's Sons, New York.

Potgieter, S.T., 2010, Eensaamheid, besigtig op 19 Desember 2010, by http://centralsa. womf.com/blog.php?id=108631 
Schurink, E.M., 1998, 'Deciding to use a qualitative research approach', in A.S. de Vos (ed.), Research at grass roots. A primer for the caring professions, JL van Schaik, Pretoria.

Shaver, P. \& Hazan, C., 1989, 'The relationship of interpersonal competence and skills to reported loneliness across time', in M. Hojat \& R. Crandall (eds.), Loneliness: Theory, research, and applications, Sage, London.

Smit, N., 2000, Wanneer 'n vrou treur, Lux Verbi.BM, Wellington.

Spitzberg, B.H. \& Hurt, H.T., 1989, 'The relationship of interpersonal competence and skills to reported loneliness across time', in M. Hojat \& R. Crandall (eds.) Loneliness: Theory, research, and applications, Sage, London.

Stokes, J.P., 1989, 'The relationship of interpersonal competence and skills to reported loneliness across time', in M. Hojat \& R. Crandall (eds.), Loneliness: Theory, research, and applications, Sage, London.
Swinton, J. \& Mowat, H., 2006, Practical Theology and qualitative research, SCM, London.

Van den Berg, J-A., 2006, "n Verandering in Tongval...? 'n Verwoord(-beeld)-ing van pastoraal-teologiese perspektiewe', Praktiese Teologie in Suid-Afrika (2), 164-181.

Van Niekerk, R., 2002, Verlies, pyn en die verwerking daarvan: 'n Praktiese begeleiding vir mense wat die beproewing van die dood ervaar het en steeds deurleef Christelike Uitgewersmaatskappy, Vereeniging.

Weiss, R.S., 1989, 'Reflections on the present state of loneliness research', in M. Hojat \& R. Crandall (eds.), Loneliness: Theory, research, and applications, Sage, London.

Wintrob, H.L., 1989, 'Self disclosure as a marketable commodity', in M. Hojat \& R. Crandall (eds.), Loneliness: Theory, research, and applications, Sage, London.

Wood, L.A., 1989, 'Loneliness: Physiological or linguistic analysis?', in M. Hojat \& R. Crandall (eds.), Loneliness: Theory, research, and applications, Sage Publications, London. 